\title{
A One-step Coupled Amplification and Oligonucleotide Ligation Procedure for Multiplex Genetic Typing
}

\author{
Faye A. Eggerding
}

Applied Biosystems Division, Perkin-Elmer Corporation, Foster City, California 94404

A new technique, coupled amplification and oligonucleotide ligation (CAL), has been developed that allows for simultaneous multiplex amplification and genotyping of DNA. CAL is a biphasic method that combines in one assay DNA amplification by PCR with DNA genotyping by the oligonucleotide ligation assay (OLA). By virtue of a difference in the melting temperatures of PCR primer-target DNA and OLA probe-target DNA hybrids, the method allows preferential amplification of DNA during stage I and oligonucleotide ligation during stage II of the reaction. In stage $I$, target DNA is amplified using high-melting primers ( $T_{m}$ values between $68^{\circ} \mathrm{C}$ and $89^{\circ} \mathrm{C}$ ) in a two-step PCR cycle that employs a $94^{\circ} \mathrm{C}$ denaturation step and $a 2^{\circ} \mathrm{C}$ annealelongation step. In stage II, genotyping of PCR products by competitive oligonucleotide ligation with oligonucleotide probes ( $T_{m}$ values between $51^{\circ} \mathrm{C}$ and $67^{\circ} \mathrm{C}$ ) located between the PCR primers is accomplished by several cycles of denaturation at $94^{\circ} \mathrm{C}$ followed by anneal-ligation at $55^{\circ} \mathrm{C}$. Ligation products are fluorochromelabeled at their 3 ' ends and analyzed electrophoretically on a fluorescent DNA sequencer. The CAL procedure has been used successfully to analyze human genomic DNA for cystic fibrosis (CF) alleles. Because product detection occurs concurrently with target amplification, the technique is rapid, highly sensitive, and specific and requires minimal sample processing. enetic typing involves the identification of sequence polymorphisms and/or genetic mutations (mutant alleles) in a defined segment of genomic DNA by any one of a variety of molecular methods. Numerous strategies of in vitro genetic typing have been developed based on the biologic processes of DNA replication, DNA ligation, and RNA transcription. ${ }^{(1-7)}$ All of these methods are similar in that they require initial in vitro enzymatic amplification of a specific genomic DNA segment followed by analysis of the amplification products for molecular changes. PCR, the first and most common amplification protocol, is a powerful method for amplifying minute amounts of DNA or mRNA, and it has achieved widespread application, particularly for characterization of genetic diseases, identification of disease susceptibility loci, and diagnosis of cancer. ${ }^{(8-14)}$

Most allelic sequence variants leading to human disease involve single-base substitutions and small deletion or insertion mutations. The distinction between closely related gene sequences may be accomplished by using short synthetic oligonucleotide probes under stringent hybridization conditions ${ }^{(15,16)}$ or by using the substrate specificity of DNAmodifying enzymes such as restriction enzymes or ligases to identify known sequence variants. $^{(3,17-20)}$ The oligonucleotide ligation assay (OLA), as originally described by Landegren et al., ${ }^{(3)}$ is a very useful diagnostic technique that can be performed after a primary PCR amplification for detection of alternative DNA sequences in very large and complex genomes. The principle of the OLA reaction is based on the ability of ligase to covalently join two diagnostic oligonu- cleotides as they hybridize adjacent to one another on a DNA target. If sequences at the probe junctions are not perfectly base-paired, the probes will not be joined by ligase. The exquisite ability of thermostable ligase to discriminate potential single-base-pair differences when positioned at the $3^{\prime}$ end of the upstream probe provides the opportunity for single-base resolution with high accuracy. ${ }^{(17)}$

Because procedures for genotyping DNA are being performed with increasing frequency in both clinical and research laboratories, there is a demand for the development of efficient, simple, and low-cost procedures for DNA typing that are highly reproducible and easily automated. The technique of multiplex PCR fulfills these criteria because in one reaction multiple and widely separated genetic loci can be amplified simultaneously. However, detection of mutant alleles or known sequence polymorphisms after multiplex PCR requires post-PCR manipulation and/or separation of the amplified reaction products. Current PCR-based methods for discriminating alternative nucleic acid sequences depend either on PCR product size or sequence and are not ideal for screening large numbers of samples. Methods that link enzymatic DNA amplification to probe-based detection methods in a one-step, single-tube reaction procedure would greatly facilitate genetic typing in a clinical setting. In this paper a one-step, single-tube coupled target amplification and probe ligation (CAL) procedure is described that can both amplify and screen genomic DNA at the same time in a multiplex format. All of the reactants are added simul- 
TABLE 1 PCR Primers Used for CAL

\begin{tabular}{|c|c|c|c|}
\hline $\begin{array}{l}\text { Gene } \\
\text { location }\end{array}$ & Primer sequence $\left(5^{\prime} \rightarrow 3^{\prime}\right)^{a}$ & $T_{\mathrm{m}}\left({ }^{\circ} \mathrm{C}\right)^{\mathrm{b}}$ & Fragment size (bp) \\
\hline Exon 3 & $\begin{array}{l}\text { F: GAATGGGATAGAGAGCTGGCTTCAAAGAAAAATCCT } \\
\text { R: CCTTTATATTTTTACACCTATTCACCAGATTTCGTAGTC }\end{array}$ & $\begin{array}{l}81.5 \\
76.3\end{array}$ & 213 \\
\hline Exon 4 & $\begin{array}{l}\text { F: CTAAGAGTTTCACATATGGTATGACCCTC } \\
\text { R: CCCTTACTTGTACCAGCTCACTACCTA }\end{array}$ & $\begin{array}{l}69.1 \\
68.6\end{array}$ & 451 \\
\hline Exon 5 & $\begin{array}{l}\text { F: ATTTCTGCCTAGATGCTGGGAAATAAAAC } \\
\text { R: CCAGGAAAACTCCGCCTTTCCAGTTG }\end{array}$ & $\begin{array}{l}73.3 \\
78.3\end{array}$ & 402 \\
\hline Exon 7 & $\begin{array}{l}\text { F: CTCTAGAGACCATGCTCAGATCTTCCAT } \\
\text { R: GCAAAGTTCATTAGAACTGATCTATTGACT }\end{array}$ & $\begin{array}{l}71.5 \\
68.5\end{array}$ & 416 \\
\hline Exon 9 & $\begin{array}{l}\text { F: TATACAGTGTAATGGATCATGGGCCATGT } \\
\text { R: GTGCAAGATACAGTGTTGAATGTGGTGCA }\end{array}$ & $\begin{array}{l}74.2 \\
76.6\end{array}$ & 578 \\
\hline Exon 10 & $\begin{array}{l}\text { F: GTGCATAGCAGAGTACCTGAAACAGGAAGTA } \\
\text { R: TGATCCATTCACAGTAGCTTACCCATAGAGG }\end{array}$ & $\begin{array}{l}74.3 \\
75.5\end{array}$ & 503 \\
\hline Exon 11 & $\begin{array}{l}\text { F: CAACTGTGGTTAAAGCAATAGTGTGATATATGATTACAT } \\
\text { R: GCACAGATTCTGAGTAACCATAATCTCTACCAAATC }\end{array}$ & $\begin{array}{l}75.7 \\
76.4\end{array}$ & 425 \\
\hline Exon 12 & $\begin{array}{l}\text { F: GTGAATCGATGTGGTGACCATATTGTAATGCATGTA } \\
\text { R: ACCATGCTACATTCTGCCATACCAACAATGGTGAAC }\end{array}$ & $\begin{array}{l}80.7 \\
83.6\end{array}$ & 339 \\
\hline Exon 13 & $\begin{array}{l}\text { F: CTCATGGGATGTGATTCTTTCGACCAATTTAGTG } \\
\text { R: AGAATCTGGTACTAAGGACAGCCTTCTCTCTAA }\end{array}$ & $\begin{array}{l}80.2 \\
74.0\end{array}$ & 297 \\
\hline Exon 14b & $\begin{array}{l}\text { F: CATCACAAATAATAGTACTTAGAACACCTAGTACAGCTGCT } \\
\text { R: GCCCTGAACTCCTGGGCTCAAGTGATCCTCCTGC }\end{array}$ & $\begin{array}{l}76.4 \\
88.9\end{array}$ & 476 \\
\hline Intron 19 & $\begin{array}{l}\text { F: AATTATAATCACCTTGTGGATCTAAATTTCAGTTGACTTGTC } \\
\text { R: TTTAAGACATACCCTAAATCTAAGTCAGTGTTTTCTAATAAC }\end{array}$ & $\begin{array}{l}79.1 \\
74.7\end{array}$ & 300 \\
\hline Exon 19 & $\begin{array}{l}\text { F: GCCCGACAAATAACCAAGTGACAAATAG } \\
\text { R: GCTAACACATTGCTTCAGGCTACTGGG }\end{array}$ & $\begin{array}{l}73.9 \\
75.0\end{array}$ & 454 \\
\hline Exon 20 & $\begin{array}{l}\text { F: GGTCAGGATTGAAAGTGTGCAACAAGGTTTGAATGAATAAG } \\
\text { R: CTATGAGAAAACTGCACTGGAGAAAAAAAAGACAGCAATG }\end{array}$ & $\begin{array}{l}84.7 \\
82.7\end{array}$ & 473 \\
\hline Exon 21 & $\begin{array}{l}\text { F: AATGTTCACAAGGGACTCCAAATATTGCTGTAGTATTTG } \\
\text { R: TCCAGTCAAAAGTACCTGTTGCTCCAGGTATGTTAGGGTA }\end{array}$ & $\begin{array}{l}80.2 \\
83.7\end{array}$ & 483 \\
\hline
\end{tabular}

aprimer sequences indicated in boldface type are from Zielenski et al. ${ }^{(26)}$

${ }^{\mathrm{b}} T_{\mathrm{m}}$ values were calculated by nearest-neighbor analysis as described by Breslauer et al. ${ }^{(27)}$

taneously in one tube, and product detection occurs together with target amplification. Manual work and sample handling are minimized; therefore, large numbers of samples can be handled and the risk of PCR carryover contamination is reduced to a minimum. The simplicity of the method makes it readily amenable to automation. To demonstrate its utility, this technique has been applied successfully for mutliplex amplification and detection of cystic fibrosis (CF) mutations in one reaction and in a single gel lane.

\section{MATERIALS AND METHODS}

\section{Source of DNA}

Human genomic DNA was prepared from peripheral blood-nucleated cells and buccal cells. DNA was isolated from whole blood using the guanidinium method for extracting DNA. ${ }^{(21)}$ DNA was extracted from buccal cells by boiling as described previously. ${ }^{(18)}$

\section{Oligonucleotide Primers and Probes}

Sequences of the primers and probes used in this study are given in Tables 1 and 2 (below). All primers used for PCR and probes used for oligonucleotide ligation were synthesized on an Applied Biosystems model 394 DNA synthesizer using standard cyanoethyl phosphoramidite chemistry. Reporter probes for oligonucleotide ligation were chemically 5'-end phosphorylated using 5'phosphate-ON (5210-1, Clontech Laboratories, Inc., Palo Alto, CA) and 3'end labeled with the fluorescent dye FAM-NHS ester (5-carboxy-fluorescein). FAM-labeled, phosphorylated oligonucleotides were purified from nonconjugated oligonucleotides by reverse-phase high-pressure liquid chromatography (HPLC). ${ }^{(22)}$ PCR primers and genotypespecific oligonucleotide probes were $\mathrm{pu}$ rified using oligonucleotide purification cartridges (Applied Biosystems). Purified primers and probes were lyophilized, resuspended in sterile distilled water, and quantified spectrophotometrically.

\section{Conditions for CAL}

Optimization experiments led to the following protocol for performing CAL reactions. CAL reactions were performed in a total volume of $50 \mu \mathrm{l}$ in $0.2-\mathrm{ml}$ thinwall tubes in a Perkin-Elmer 9600 DNA thermocycler. Each reaction contained 2 $\mu l$ of DNA (100-500 ng) extracted from peripheral blood or $2 \mu$ l of DNA from boiled mucosal cell lysates, primers for multiplex PCR (200-800 nM), and oligonucleotide probes $(2.5-15.0 \mathrm{nM})$ in buffer containing $10 \mathrm{~mm}$ Tris- $\mathrm{HCl}(\mathrm{pH}$ 8.3), $50 \mathrm{~mm} \mathrm{KCl}, 4.5-6.0 \mathrm{~mm} \mathrm{MgCl}_{2}, 1$ $\mathrm{mM} \mathrm{NAD}^{+}, 200-600 \mu \mathrm{M}$ each dATP, dCTP, dGTP, and dTTP, 5 units of cloned Taq DNA polymerase, and 20100 units of Taq DNA ligase. ${ }^{(23)}$ To avoid contamination, tips with barriers were used for all pipettes. Following a 5-min denaturation at $94^{\circ} \mathrm{C}$, samples were subjected to 25 PCR amplification cycles, each consisting of $94^{\circ} \mathrm{C}$ for $30 \mathrm{sec}$ and $72^{\circ} \mathrm{C}$ for $1.5 \mathrm{~min}$. This was followed by heating at $98^{\circ} \mathrm{C}$ for at least $5 \mathrm{~min}$ and then 5-10 oligonucleotide ligation 
cycles of $94^{\circ} \mathrm{C}$ for $30 \mathrm{sec}$ and $55^{\circ} \mathrm{C}$ for 2 $\min$.

\section{Detection of Amplification-Ligation Products}

A 0.5 - to $2.0-\mu l$ aliquot of each CAL reaction was combined with 10 fmoles of internal lane standard consisting of oligomers $30-70$ bases in size, labeled with the dye ROX (6-carboxy-X-rhodamine) and $4 \mu \mathrm{l}$ of formamide loading buffer. Samples were heat denatured at $100^{\circ} \mathrm{C}$ for $5 \mathrm{~min}$, cooled rapidly on ice, and loaded onto an $8 \%$ polyacrylamide denaturing sequencing gel. Gels were electrophoresed for 3-4 hr at $1500 \mathrm{~V}$ in an Applied Biosystems model 373A fluorescent DNA sequencer. The location and relative quantity of ligation products were automatically recorded with GENESCAN 672 software (Applied Biosystems) as described previously. ${ }^{(18,24)}$ PCR products were analyzed by electrophoresis in 3\% MetaPhor agarose (FMC BioProducts, Rockland, ME) gels in $1 \times$ TBE buffer at $100 \mathrm{~V}$ for 5-6 hr and visualized by staining with $0.5 \mu \mathrm{g} / \mathrm{ml}$ of ethidium bromide.

\section{Model}

The cystic fibrosis transmembrane conductance regulator (CFTR) gene, with over 300 known alleles, was used as the model system to develop the CAL procedure. ${ }^{(25)}$ High-melting-temperature PCR primers $\left(T_{\mathrm{m}}\right.$ values between $68.5^{\circ} \mathrm{C}$ and $88.9^{\circ} \mathrm{C}$ ) were used to amplify CFTR ex- onic and intronic sequences in a twostep, multiplex PCR format (Table 1). ${ }^{(26)}$ CFTR-amplified targets were genotyped by competitive oligonucleotide ligation with short oligonucleotide probes $\left(T_{\mathbf{m}}\right.$ values between $51.4^{\circ} \mathrm{C}$ and $67.7^{\circ} \mathrm{C}$ ) (Table 2).

\section{RESULTS}

\section{Strategy for CAL of Genomic DNA}

The hypothesis was that PCR and oligonucleotide ligation could be carried out together without significant impairment of amplification or ligation if the melting temperature of the target-specific oligonucleotide probes (OLA) was considerably lower than the anneal-elongation temperature of the PCR reaction. Figure 1 illustrates the general framework of the procedure. Initially, conditions are weighted in favor of PCR to allow amplification of desired allelic segments from genomic DNA to provide templates for the ligation reaction. A two-step PCR cycle with an anneal-elongation temperature of $72^{\circ} \mathrm{C}$ was carried out using primers designed to anneal at high temperatures (see Table 1) and a reaction buffer system developed to support both PCR and oligonucleotide ligation. Allelic discrimination by competitive oligonucleotide ligation is accomplished in stage II simply by lowering the temperature to $55^{\circ} \mathrm{C}$ to allow the oligonucleotide probes (Table 2) present in the reaction mixture to align and hybridize with their ampli- fied target sequences. Reporter (downstream, invariant) oligonucleotide probes contained a $3^{\prime}$-fluorophore (FAM) label for detection of ligation products and for blockage of $3^{\prime}$-end extension by Taq polymerase. Taq polymerase extension from the 3 ' ends of genotype-specific (upstream, diagnostic) oligonucleotides may occur but would be undetectable because it prevents ligation. Diagnostic oligonucleotide probes have $5^{\prime}$-poly(A) extensions of different lengths for separation of allelic ligation products by electrophoretic mobility. ${ }^{(18,24)}$

\section{Optimization of the PCR Reaction (Stage I)}

The CFTR gene was chosen as a model system. Target DNA samples representing the different CF alleles were generated by amplification of 13 exonic and 1 intronic segment of the CFTR gene. Amplification priming sites for CFTR exons were selected from intronic regions bordering each exon; CFTR intron 19 sequences were amplified from primers located $\sim 10 \mathrm{~kb}$ from the $5^{\prime}$ intron-exon junction. ${ }^{(26)}$

Primer construction and annealing temperature appeared to have a significant effect on the production of discrete, reproducible amplification products without background. Two different types of primers were tested. One set consisted of short ( $\sim 20$ bases), low-melting-temperature primers $\left(T_{\mathrm{m}} \sim 61^{\circ} \mathrm{C}\right)$, originally developed by Zielenski et al. ${ }^{(26)} \mathrm{A}$ second

TABLE 2 Oligonucleotide Probes for Detection of CF Mutations by CAL

\begin{tabular}{|c|c|c|c|c|c|c|c|c|}
\hline \multirow[b]{2}{*}{ Mutation } & \multirow[b]{2}{*}{$\begin{array}{l}\text { Wild-type probe } \\
\left(5^{\prime} \rightarrow 3^{\prime}\right)^{\mathrm{a}}\end{array}$} & & \multirow[b]{2}{*}{$\begin{array}{l}\text { Mutant probe } \\
\left(5^{\prime} \rightarrow 3^{\prime}\right)^{\mathrm{a}}\end{array}$} & & \multirow[b]{2}{*}{$\begin{array}{l}\text { Common probe } \\
\left(5^{\prime} \rightarrow 3^{\prime}\right)^{b}\end{array}$} & & \multicolumn{2}{|c|}{$\begin{array}{l}\text { Ligation product } \\
\text { size (bases) }\end{array}$} \\
\hline & & & & & & & $\begin{array}{l}\text { wild } \\
\text { type }\end{array}$ & mutant \\
\hline $\mathrm{AF} 508$ & $\left(a_{21}\right)$-CACCATTAAAGAAAATATCATCTT & $(59.5)^{\mathrm{C}}$ & $\left(a_{20}\right)$ GGCACCATTAAAGAAAATATCAT & $(62.1)^{c}$ & TGGTGTTTCCTATGATGAATAT & $(58.5)^{\mathrm{C}}$ & 57 & 65 \\
\hline $\begin{array}{l}\text { G542X } \\
\text { G551D }\end{array}$ & $\begin{array}{l}\text { GTGATTCCACCTTCTCC } \\
\left(a_{2}\right) \text {-TAAAGAAATTCTTGCTCGITGAC }\end{array}$ & $\begin{array}{l}(52.8) \\
(63.1)\end{array}$ & $\begin{array}{l}\text { GTGTGATTCCACCTTCTCA } \\
\text { TAAAGAAATTGTTGCTCGTTGAT }\end{array}$ & $\begin{array}{l}(57.0) \\
(62.8)\end{array}$ & $\begin{array}{l}\text { AAGAACTATATTGTCITTCTCT } \\
\text { CTCCACTCAGTGTGATTCCA }\end{array}$ & $\begin{array}{l}(51.4) \\
(60.1)\end{array}$ & $\begin{array}{l}39 \\
45\end{array}$ & $\begin{array}{l}41 \\
43\end{array}$ \\
\hline W1282X & $\left(a_{5}\right)$-TATCACTCCAAAGGCTTTCCTC & $(64.7)$ & (a) $)$-TATCACTCCAAAGGCTTTCCTT & $(64.5)$ & CACTGTTGCAAAGTTATTGAATCC & $(65.3)$ & 51 & 53 \\
\hline N1303K & $\left(c_{4}\right)$-TATTTTTTCTGGAACATTTAGAAAAAAC & $(65.8)$ & $\left(c_{6}\right) \cdot$ TATTTTTTCTGGAACATTTAGAAA AAAG & $(65.9)$ & TTGGATCCCTATGAACAGTGGAG & $(67.3)$ & 55 & 57 \\
\hline 3905 ins $T$ & (a 10$)$-AAGAGTACTTTGTTATCAGSTTTTTT & (62.2) & $\left(a_{12}\right)$-AAGAGTAGTTTGTTATCAGSTTTTTTT & (63.7) & GAGACTACTGAACACTGAAGGAG & $(59.4)$ & 59 & 62 \\
\hline $3849+10 \mathrm{kbC}->\mathrm{T}$ & $\left(a_{25}\right)$-ATCTGTTGCAGTAATAAAATGGC & $(62.9)$ & $\left(\mathrm{a}_{26}\right)$-CATCTGTTGCAGTAATAAAATGGT & (62.9) & GAGTAAGACACCCTGAAAGGAA & (62.2) & 70 & 72 \\
\hline $\begin{array}{l}3849+4 A->A \\
3659 \text { del }\end{array}$ & $\begin{array}{l}\text { (a)-CCTGGCCAGAGGGTGA } \\
\left(a_{2}\right) \text {-CAACAGAAGGTAAACCTAC }\end{array}$ & $\begin{array}{l}(61.2) \\
(50.9)\end{array}$ & $\begin{array}{l}\text { CTGGCCAGAGGGTGG } \\
\text { CGAACAGAAGGTAAACCTA }\end{array}$ & $\begin{array}{l}(58.4) \\
(54.2)\end{array}$ & $\begin{array}{l}\text { GATTTGAACACTGCTTGCT } \\
\text { CAAGTCAACCAAACCATACA }\end{array}$ & $\begin{array}{l}(57.4) \\
(58.1)\end{array}$ & $\begin{array}{l}36 \\
41\end{array}$ & $\begin{array}{l}34 \\
39\end{array}$ \\
\hline $\mathrm{R} 117 \mathrm{H}$ & ACTAGATAAATCGCGATAGAGC & $(60.1)$ & $\left(a_{2}\right)$-ACTAGATAAATCGCGATAGAGT & $(57.2)$ & GTTCCTCCTTGTTATCCGGGT & $(66.3)$ & 43 & 45 \\
\hline R1162X & (a)-ITTCAGATGCGATCTGTGAGCC & $(69.3)$ & (a)-TTTCAGATGCGATCTGTGAGCT & $(66.7)$ & GAGTCTTTAAGTTCATTGACATGC & (62.3) & 47 & 49 \\
\hline $1717 \cdot 1 \mathrm{G}->\mathrm{A}$ & $\left(\mathrm{a}_{4}\right)$-TCTGCAAACTTGGAGATGTCC & $(64.3)$ & $\left(a_{6}\right)$-TCTGCAAACTTGGAGATGTCT & $(61.5)$ & TATTACCAAAAATAGAAAAT TAGAGA & (59.2) & 51 & 53 \\
\hline $621+1 \mathrm{G}->\mathrm{T}$ & (a 7 )-TATGTTTAGTTIGATTTATAAGAAGG & $(59.3)$ & (ag)-TATGTTTAGTTTGATITATAAGAAGT & $(56.9)$ & TAATACTTCCTTGCACAGGCCC & $(67.7)$ & 55 & 57 \\
\hline R553X & $\left(a_{18}\right)$-TGSTAAAGAAATTCTTGCTCG & $(62.4)$ & $\left(a_{20}\right)$-TTGCTAAAGAAATTOTTGCTCA & $(62.1)$ & TTGACOTCCACTCAGTGTGA & $(60.5)$ & 59 & 62 \\
\hline $2789+5 \mathrm{G}->\mathrm{A}$ & $\left(c_{27}\right)$-CACAATAGGACATGGAATAC & $(54.1)$ & (c 25$)$-CACAATAGGACATGGAATAT & $(53.8)$ & TCACTTTCCAAGGAGGCAC & $(62.3)$ & 66 & 64 \\
\hline
\end{tabular}

${ }^{a} 5$ '-Poly $(A)$ or poly $(C)$ extensions were added to wild-type and mutant probes for multiplex detection of alleles by gel electrophoresis.

'Probes were 5'-phosphorylated and fluorescently labeled at their 3 ' ends with the fluorescein dye FAM.

${ }^{\mathrm{c}} T_{\mathrm{m}}$ values calculated by nearest-neighbor analysis as described by Breslauer et al. ${ }^{(27)}$ 

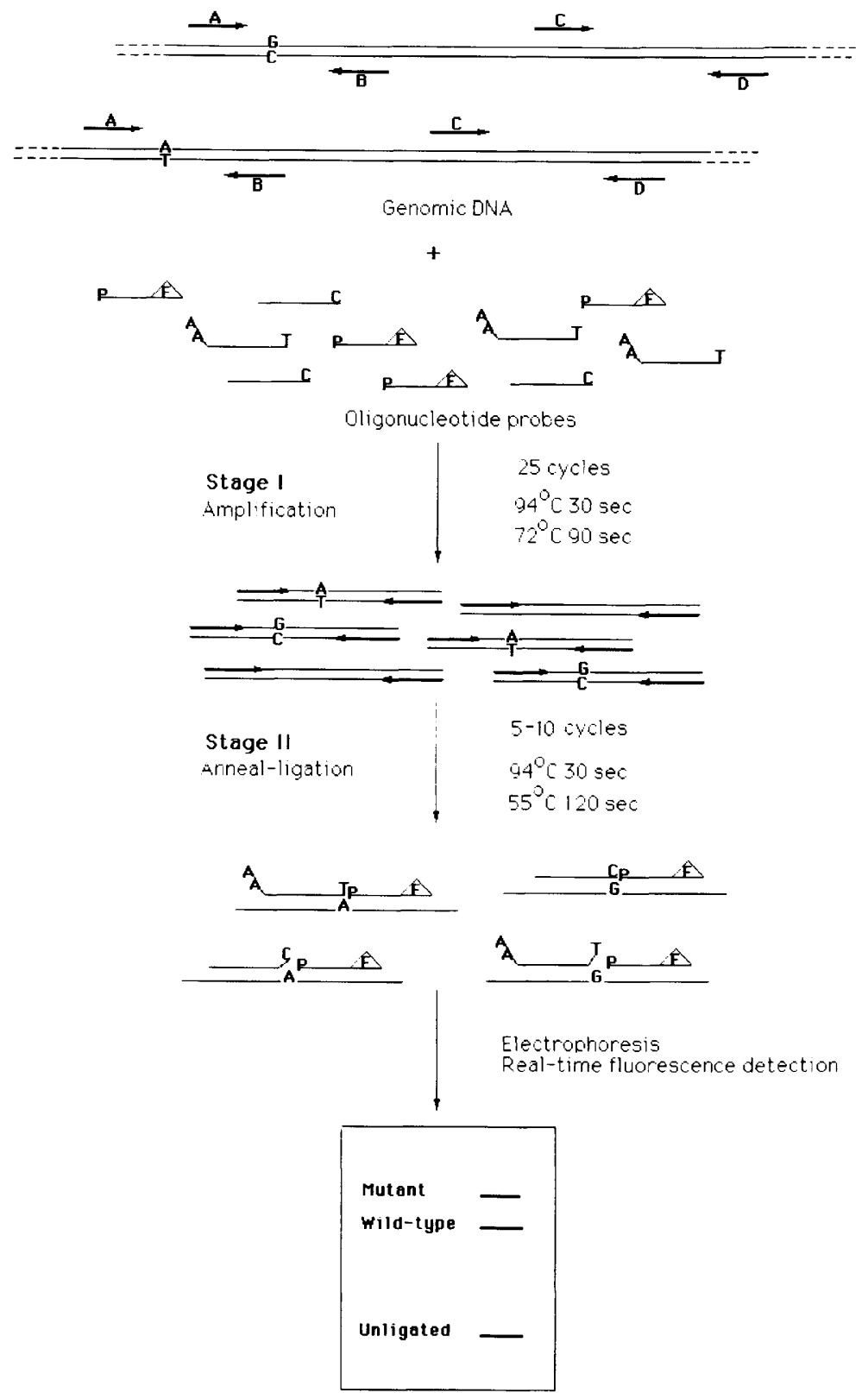

FIGURE 1 A schematic representation of the CAL method. The basis of the method is use of high-melting-temperature PCR primers in a two-step PCR cycle with an anneal-elongation temperature that is above the melting temperature of the oligonucleotide probes present in the reaction mix. Amplification of genomic target occurs in stage I. Allelic variants ( $G \rightarrow$ A transition) in the amplified target are distinguished by oligonucleotide ligation in stage Il. A set of three probes is required to analyze each alternative sequence, one for each allele and one reporter 5'-phosphorylated probe labeled with a fluorophore (F) at its 3' end. Probes mismatched to the target by a single nucleotide at their junctions are not ligated. Ligation products are detected using a fluorescent DNA sequencer.

set of longer ( $\sim 33$ bases), high-meltingtemperature primers $\left(T_{\mathrm{m}} \sim 77^{\circ} \mathrm{C}\right)$ was designed for use in a two-step cycle linked to target detection by probe-based oligonucleotide ligation (CAL). Many of these primers (Table 1) are longer extensions of the low-melting-temperature primers used by Zielenski et al. ${ }^{(26)}$ The melting temperatures of the PCR primers given in Table 1 are not exact for the PCR conditions used but, rather, represent estimates based on base sequence and nearest-neighbor analysis. ${ }^{(27)}$ The effect of primer annealing temperature on amplification of CFTR gene segments using low- and high-melting-temperature PCR primers is demonstrated in Figure 2. Multiple nonspecific fragments are seen in ethidium bromide-stained gels when the primer annealing temperature is $55^{\circ} \mathrm{C}$ (Fig. 2A,B), indicating that at this temperature ectopic misprimed products are formed by primer annealing to sites on the DNA other than the correct priming sites. A marked improvement in specificity resulted when high-meltingtemperature primers were used at an annealing temperature of $72^{\circ} \mathrm{C}$. Under these conditions, primer-directed amplification at each locus became optimally efficient and CFTR gene-specific fragments were the major amplification products (Fig. 2B, cf. top and bottom). At $72^{\circ} \mathrm{C}$ the low-melting-temperature primers have poor amplification efficiency, leading to little or no PCR product accumulation (Fig. 2A, lanes 5-8). Interestingly, the two-temperature PCR format $\left(94^{\circ} \mathrm{C}, 30 \mathrm{sec} ; 72^{\circ} \mathrm{C}, 1.5 \mathrm{~min}\right)$ with highmelting-temperature primers afforded more specificity in PCR than a standard three-cycle PCR $\left(94^{\circ} \mathrm{C}, 30 \mathrm{sec} ; 55^{\circ} \mathrm{C}, 30\right.$ $\mathrm{sec} ; 72^{\circ} \mathrm{C}, 1.5 \mathrm{~min}$ ) using the same primers but carried out utilizing the hot start PCR technique (data not shown). ${ }^{(28)}$ Only primers with high melting temperatures were used for all subsequent experiments (Table 1).

Amplifications were initially performed separately for each PCR primer pair and then combined into various multiplex formats, as shown in Figure 3. Although nonspecific primer artifacts may increase with each added primer, all primer pairs used in this study gave clean signals alone and in various multiplex formats (cf. Figs. 2 and 3). As little as $1 \mathrm{ng}$ of purified genomic DNA template produced easily visible amounts of multiplex PCR product on ethiduim bromide-stained MetaPhor agarose gels (data not shown). The multiplex PCR reaction parameters and cycling profile were stringently optimized to provide a robust PCR with maximal product yields and negligible amounts of undesired, spurious PCR bands. For example, the magnesium concentration was varied from 1.5 to $6.0 \mathrm{~mm}$ in reactions with the dNTP concentrations fixed at 200, 400, or $600 \mu \mathrm{M}$; even at high magnesium concentrations, mispriming at nontarget sites was not evident. Magnesium and dNTP requirements increased, as expected, when the number of amplicons in the multiplex PCR was increased. Higher magnesium concentrations (4.5- 
A.

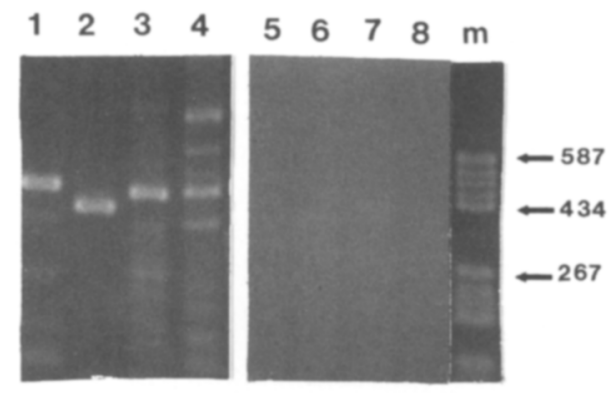

B.

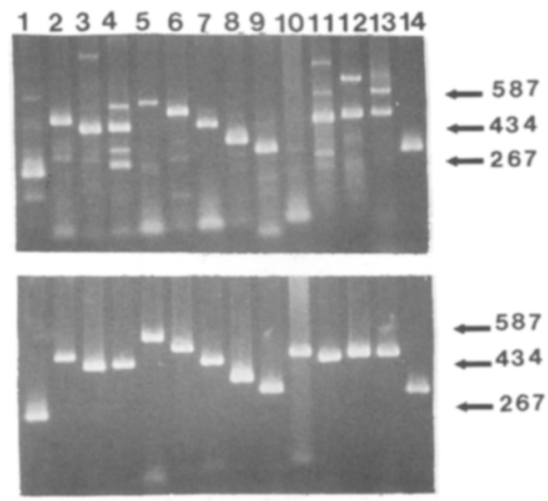

FIGURE 2 Effect of different anneal-elongation temperatures and primer length on PCR amplification from the CFTR gene. The template was human genomic DNA. $(A)$ The reactions used lower-melting-temperature primers ${ }^{(26)}$ to amplify CFTR exons 10 (lanes 1,5), 11 (lanes 2,6), 20 (lanes 3,7 ), and 21 (lanes 4,8 ). (Lanes $1-4$ ) The results using a three-step cycle are as follows: $94^{\circ} \mathrm{C}$ denaturation, $30 \mathrm{sec} ; 55^{\circ} \mathrm{C}$ annealing, $30 \mathrm{sec} ; 72^{\circ} \mathrm{C}$ elongation, $1.5 \mathrm{~min}$. (Lanes $5-8$ ) The reactions used a two-step cycle of $94^{\circ} \mathrm{C}$ denaturation: $30 \mathrm{sec}$ and $72^{\circ} \mathrm{C}$ anneal-elongation, $1.5 \mathrm{~min}$. PCRamplified DNA fragments were separated in 3\% MetaPhor agarose gels in $1 \times \mathrm{TBE}$ and stained with ethidium bromide. (B) Higher-melting-temperature primers (see Table 1) were used to amplify CFTR exons 3 (lane 1), 4 (lane 2), 5 (lane 3), 7 (lane 4), 9 (lane 5), 10 (lane 6), 11 (lane 7), 12 (lane 8), 13 (lane 9), 14b (lane 10), 19 (lane 11), 20 (lane 12), 21 (lane 13), and intron 19 (lane 14) in a three-step PCR cycle (top) or a two-step cycle (anneal-elongation at $72^{\circ} \mathrm{C}$, bottom). Arrows indicate the positions of HaeIII-digested pBR322 DNA size markers.

$6.0 \mathrm{~mm}$ ) were chosen for use in the PCR reaction to ensure efficient ligation in the subsequent probe ligation step (stage II).

\section{Optimization and Characterization of the CAL Reaction (Stage II)}

The results of a series of titration experiments resulted in the optimized CAL buffer and cycling conditions indicated in Materials and Methods. Examples of multiplex amplification of CFTR amplicons performed under CAL conditions and, for comparison, under standard optimized multiplex PCR conditions, can be seen in Figure 3. Except for a slight reduction in product yield for some fragments, multiplex amplification of 14 CFTR amplicons under CAL conditions gave results identical to those obtained under standard conditions for 14-plex CFTR PCR (Fig. 3A, cf. lanes 1 and 2). The feasibility of using check mucosal cellular DNA extracted simply by boiling in multiplex PCR under CAL conditions is demonstrated in Figure $3 \mathrm{C}$. When annealing and elongation are both carried out at $72^{\circ} \mathrm{C}$, the diagnostic OLA probes that are located between each set of PCR primers do not block the PCR reaction significantly. However, if a three-step
PCR cycle was done with an annealing step at $55^{\circ} \mathrm{C}$ followed by elongation at $72^{\circ} \mathrm{C}$, there was a striking reduction in the yield of PCR product (data not shown).

Figure 4 shows a comparison of multiplex typing by CAL and by the standard, two-tube PCR and OLA procedure. CFTR amplicons generated in a 14-plex PCR reaction or in stage I of the CAL protocol (Fig. 3A, lanes 1,2) were analyzed by competitive oligonucleotide ligation with 21 ligation probes specific for seven common CF mutations. The CAL results are the same as those produced when each reaction is performed separately in the standard PCR and OLA formats (Fig. 4 , cf. A with B and C).

\section{Discrimination of CFTR Alleles by CAL}

Over 300 CFTR mutant alleles resulting from either single-nucleotide substitutions (point mutations) or small deletion and/or insertion mutations have been identified. ${ }^{(25)}$ The CAL procedure was tested for its ability to detect 30 CFTR alleles distributed throughout 10 exons and 7 introns of the CFTR gene. Genomic DNA samples from peripheral blood leukocytes of normal, homozy- gous mutant and heterozygous individuals were typed for 15 CF mutant alleles using the CAL procedure. As shown in Figure 5, ligation products are allele-specific, and no mismatched ligation products, formed from incorrect ligation of a mutant probe to normal DNA (or vice versa), were evident. The minor peaks seen in the tracings in Figures 4 and 5

A.

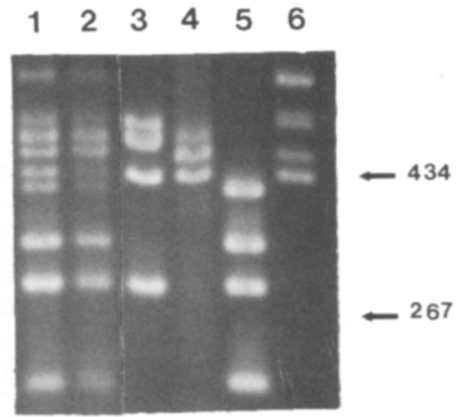

B.

C.

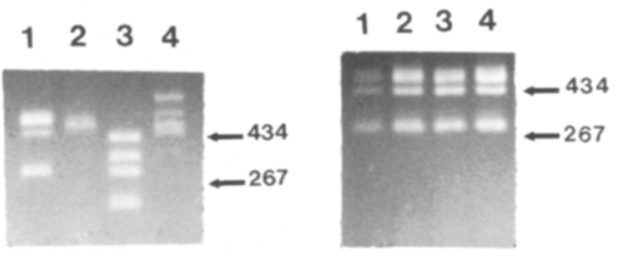

FIGURE 3 Multiplex PCR of CFTR sequences and the effect of CAL on the PCR reaction. $(A, B)$ Multiplex (14-plex) amplification of CFTR exons 3-5, 7, 9-13, 14b, and 19-21 and intron 19 in a standard PCR format $(A$, lane 1$)$ and in the CAL reaction ( $A$, lane 2$)$. Optimized multiplex PCRs for exons 10, 11, 20, and 21 and intron 19 (lane 3); exons $4,11,14 \mathrm{~b}$, and 19 (lane 4); exons $3,5,7,12$, and 13 (lane 5); and exons $4,9,10$, and 11 (lane 6 ) are shown for comparison and to enable identification of PCR products in the 14-plex reaction. (B) The results of similar amplifications performed in the presence of oligonucleotide probes in the CAL reaction. $(C)$ Effect of sample preparation. DNA from boiled cell lysates of buccal cells was amplified in the CAL reaction (lane 1) and, for comparison, in a standard, optimized multiplex PCR of CFTR exons $10,11,20$, and 21 and intron 19 (lane 2). (Lanes 3,4) Optimized PCR reactions carried out using DNA from proteinase K-treated boiled cell lysates and from phenol-chloroform-purified buccal cell DNA, respectively. All amplification and $\mathrm{CAL}$ reactions were done in $50-\mu$ l volumes, and $10-\mu l$ aliquots were separated on $3 \%$ MetaPhor agarose gels and visualized by ethidium bromide staining. Arrows mark the migration of HaelII-digested pBR322 DNA fragments. 


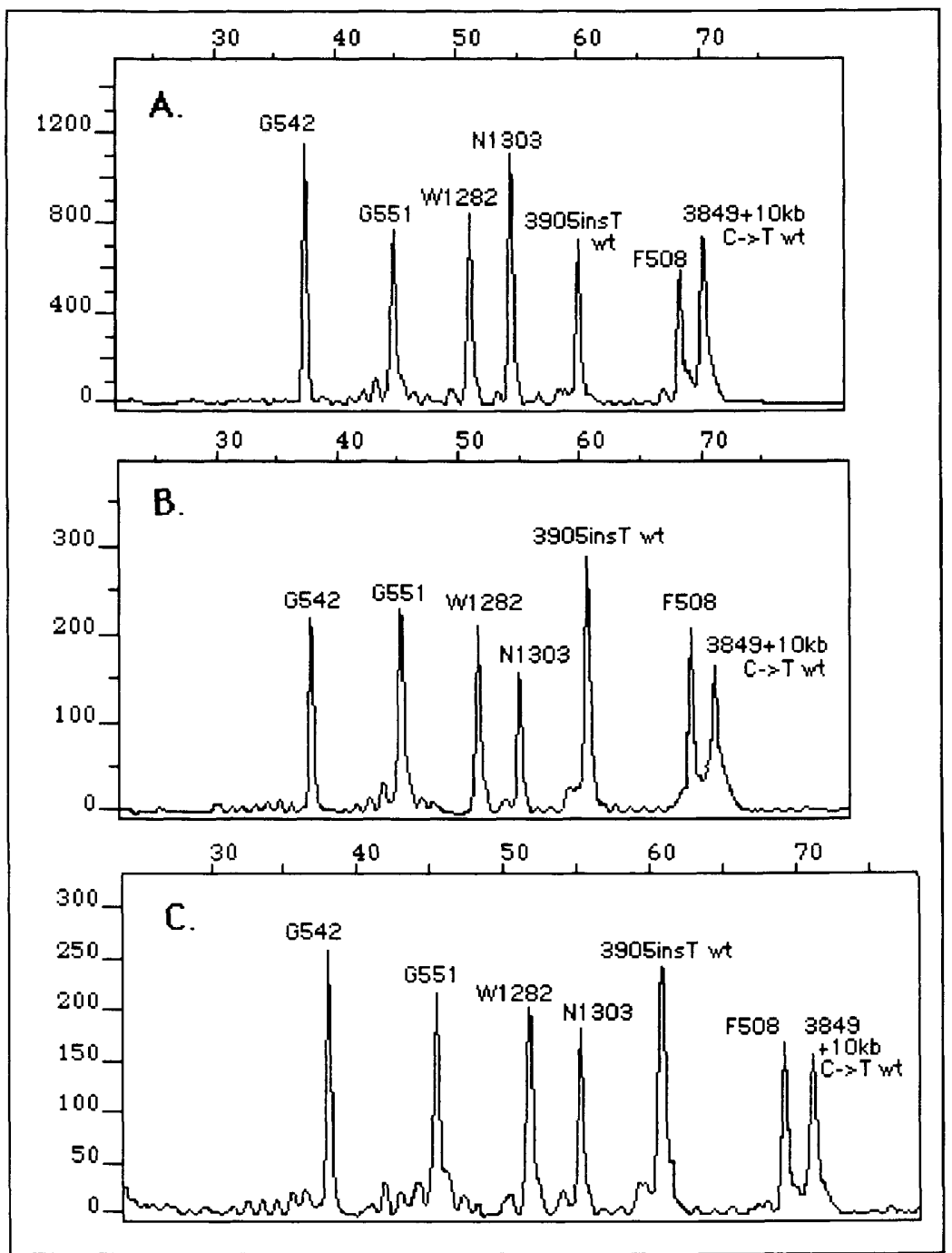

FICURE 4 Comparison of PCR followed by oligonucleotide ligation and CAL for detection of normal CF alleles. $(A)$ CFTR sequences in purified DNA from peripheral blood cells of a normal individual were amplified in a 14-plex PCR reaction, and a $2-\mu l$ aliquot was withdrawn and analyzed for CFTR alleles in a separate OLA reaction. (B) The same DNA was amplified by 14-plex PCR in the CAL procedure for simultaneous amplification and detection of the indicated CFTR alleles. $(C)$ DNA from buccal cells of a normal individual purified by boiling for $20 \mathrm{~min}$ was analyzed in a similar 14-plex CAL reaction. Three oligonucleotide probes (two allelic probes and one reporter probe) were required for analysis of each of the indicated alleles for a total of 21 oligonucleotide ligation probes. The ligation products $(1-\mu \mathrm{l}$ aliquots) were separated on $8 \%$ denaturing polyacrylamide gels in a fluorescent DNA sequencer. The electrophoretogram displays representing real-time fluorescence detection of ligation products are shown. The $y$-axes display peak heights measured by fluorescence intensity in arbitrary units, and the $x$-axes represent size in bases. Oligonucleotides $30-70$ bases long and labeled with the fluorochrome ROX were used as internal lane size markers.

most probably result from ligation of fluorescent invariant (reporter) probes with allelic "failure sequences." The poly(A) extensions present on allelic probes for sizing are vulnerable to depurination following alkali deprotection, thus forming short failure sequences that are able to ligate with fluorescent probes. Accurate allelic discrimination for the other 15 less common CF mutations was also performed sucessfully using the CAL protocol (data not shown). Control samples containing no DNA were analyzed by CAL, and no background ligation was ever observed (Fig. 5C).

\section{DISCUSSION}

The striking feature of the CAL methodology is that it can combine amplification with mutation detection in one reaction. In CAL genotyping, gene segments or DNA targets are amplified by multiplex PCR using primers with high melting temperatures; allelic discrimination occurs simply by lowering the reaction temperature to facilitate hybridization and competitive oligonucleotide ligation of allele-specific probes with lower melting temperatures. By linking the powerful techniques of multiplex amplification and multiplex oligonucleotide ligation in one reaction, CAL enables rapid, simultaneous scanning of many DNA loci with both the high sensitivity of PCR and the accuracy and exceptional single-base resolution of oligonucleotide ligation. The concept that DNA amplification and DNA genotyping can be sustained in one reaction by virtue of differences in melting behavior of primer-template and probetemplate DNA hybrids has not been explored previously. In this paper the development of this concept into a useful CAL method is described and tested by analysis of mutations in the CFTR gene.

CAL utilizes a PCR buffer modified to contain $1 \mathrm{~mm} \mathrm{NAD}{ }^{+}$and oligonucleotide probes to perform both amplification and ligation. In the present study, oligonucleotides of 26-42 nucleotides and 15-28 nucleotides were used successfully as CAL primers and probes, respectively. A two-temperature PCR reaction was carried out at a temperature above the melting temperatures of the diagnostic probes. With few exceptions, significant inhibitory effects of the oligonucleotide probes on extension by Taq DNA polymerase were not observed, indicating minimal probe hybridization at the PCR anneal-elongation temperature of $72^{\circ} \mathrm{C} .{ }^{(29)}$ Reduced yields of exon 11 amplicons were observed and may reflect the high concentration of mutant alleles in this region of the gene. PCR amplicons are ideal templates for ligation because they are relatively small in size and abundant. At low target concentrations, the ligation reaction is very slow, but at template concentrations above $1 \mathrm{nM}$, the efficiency of ligation is at least $80 \%$. Interestingly, inclusion of a 5- to $10-\mathrm{min} 98^{\circ} \mathrm{C}$ incubation step after stage I of the CAL reaction improves li- 

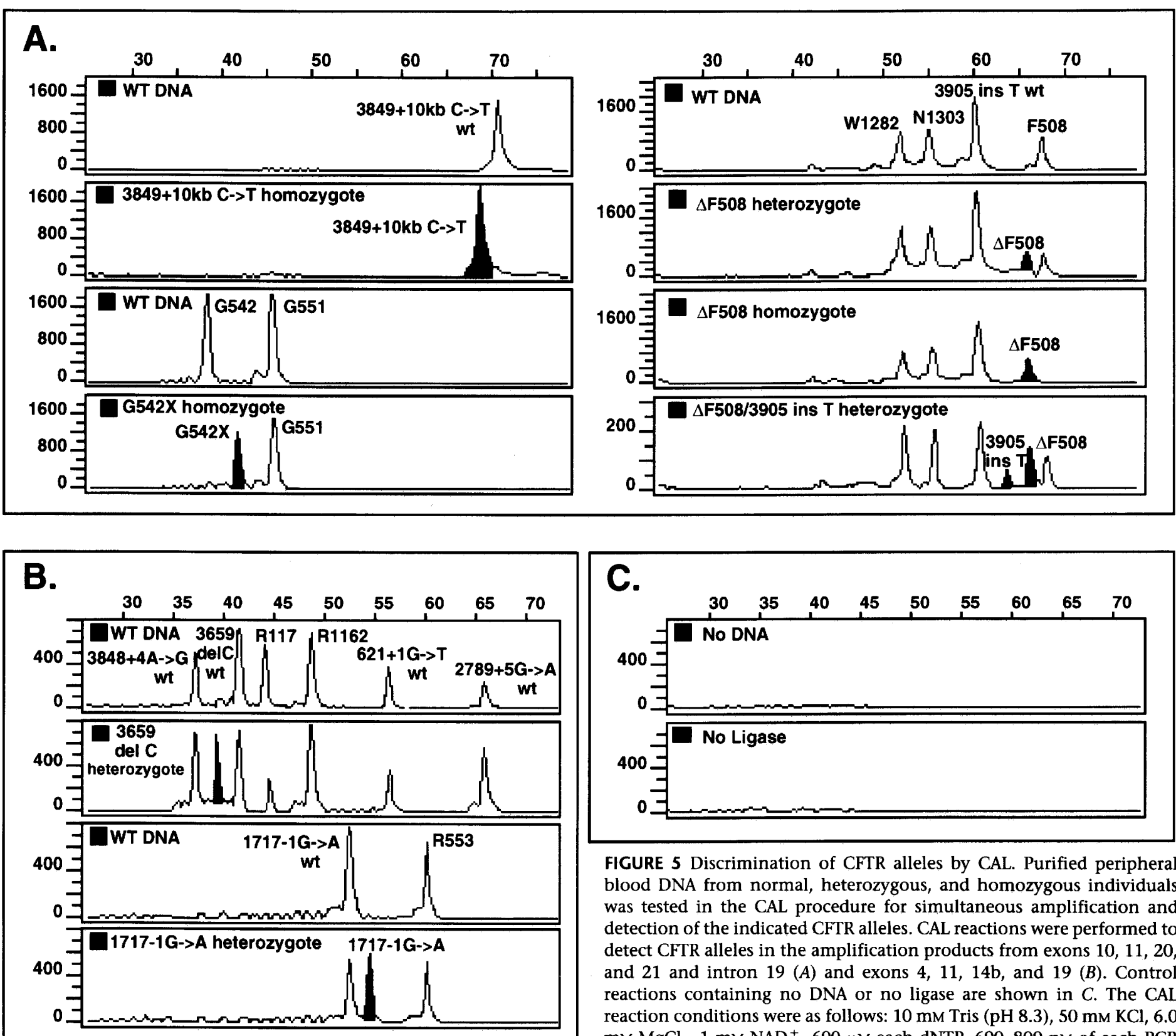

FIGURE 5 Discrimination of CFTR alleles by CAL. Purified peripheral blood DNA from normal, heterozygous, and homozygous individuals was tested in the CAL procedure for simultaneous amplification and detection of the indicated CFTR alleles. CAL reactions were performed to detect CFTR alleles in the amplification products from exons 10, 11, 20, and 21 and intron $19(A)$ and exons 4, 11, 14b, and $19(B)$. Control reactions containing no DNA or no ligase are shown in $C$. The CAL

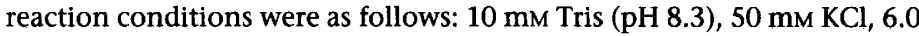
$\mathrm{mM} \mathrm{MgCl}_{2}, 1 \mathrm{mM} \mathrm{NAD}{ }^{+}, 600 \mu \mathrm{M}$ each dNTP, 600-800 nM of each PCR primer, 5 units of cloned Taq polymerase, 5-15 nM of each OLA probe (one common and two alleleic probes for analysis of each allele), 100 units of Taq DNA ligase, and 500 ng of template DNA in a 50- $\mu$ l volume. The cycle profile was as follows: $25 \mathrm{cycles}$ of $94^{\circ} \mathrm{C}$ for $30 \mathrm{sec}, 72^{\circ} \mathrm{C}$ for $1.5 \mathrm{~min}$ for amplification; incubation at $98^{\circ} \mathrm{C}$ for $10 \mathrm{~min}$; and $94^{\circ} \mathrm{C}$ for $30 \mathrm{sec}, 55^{\circ} \mathrm{C}$ for $2 \mathrm{~min}$ for 10 cycles for ligation. Aliquots $(1 \mu \mathrm{l})$ of the samples were analyzed by electrophoresis in a fluorescent DNA sequencer as described in the legend to Fig. 4. Mutant alleles are indicated as filled peaks.

gation efficiency and results in considerably increased yields of specific ligation products.

Genotype-specific ligation products are distinguished from other components in the CAL reaction mixture by both fluorescence and size. A fluorophore, coupled to the $3^{\prime}$ end of the downstream (invariant or reporter) probe, not only enables detection of ligation product but also acts to block any
3 '-end extension by Taq polymerase that may occur during the $55^{\circ} \mathrm{C}$ anneal-ligation stage of the reaction. Allelic or upstream probes contained 5' noncomplementary nucleotide extensions of different sizes for identification by electrophoretic mobility. Allelic probes, extended at their $3^{\prime}$ ends by $T a q$ polymerase, would not be detected because extension prevents ligation. Degradation of allelic probes by Taq polymerase $5^{\prime} \rightarrow 3^{\prime}$ exonuclease activity during probe annealing at $55^{\circ} \mathrm{C}$ would result in small, fluorescently labeled ligation fragments. ${ }^{(30)}$ The minor contaminating peaks seen in the tracings in Figures 4 and 5 most likely result from ligation with allelic failure sequences and not degraded allelic probes because similar bands are present in samples analyzed by the standard two-tube PCR and OLA procedure (Fig. 4). In addition, because 
probes must bind to DNA template before extension from PCR primers blocks their binding sites, there is a greater chance that PCR primers, present at higher concentrations $(0.2-0.8 \mu \mathrm{M})$, will be extended by Taq polymerase before binding and degradation of nanomolar amounts of probe can occur.

A salient feature of the stringent, twostep PCR cycle used in the CAL experiments was its high yield of correct-sized PCR products uncontaminated with spurious-sized fragments. In general, by selecting long oligonucleotide primers that have higher melting temperatures, a margin of safety and flexibility is built into the PCR reaction. ${ }^{(31)}$ Gene polymorphisms causing primer mismatches, even when present at the 3 ' terminus, can be accommodated using long, highmelting-temperature primers. ${ }^{(32)}$ Highmelting-temperature, long primers should facilitate amplification in GCrich regions, ${ }^{(33)}$ and they should also be useful as simple alternatives to nested PCR for reliable synthesis of specific amplicons.

The ability to detect accurately and reproducibily DNA sequence variants in complex genomes and to scan many loci simultaneously is essential for clinical molecular genetic testing. A molecular diagnostic test requires faithful multiplex amplification of target DNA, accurate single-base allelic discrimination with no false positives, low background, and adaptability to an automated, highthroughput format. A variety of different strategies and techniques is currently available for detection of known variations in nucleic acid sequence such as allele-specific oligonucleotide (ASO) hybridization, single-nucleotide primer extension (minisequencing), or oligonucleotide ligation. ${ }^{(16,34,35)}$ However, these methods all require post-PCR manipulation of the sample for mutation probing. In addition, development of multiplex ASO probes requires detailed knowledge of gene segment melting properties, careful control of reaction conditions, and tedious filter washing for optimal hybridization stringency. ${ }^{(36)}$

Several advantages of the CAL method over methods described previously should be emphasized. A one-step procedure has advantages relative to an analysis requiring multiple steps. Product detection occurs in the same tube with target amplification and thus requires little handling of the sample, re- ducing the chance of sample contamination. In addition, expense of reagents and preparation time is less in a one-step multiplex procedure, thus conserving costly enzymes and templates. All types of nucleic acids, including genomic DNA (eukaryotic and prokaryotic), plasmid, phage or viral DNA, cDNA, and even $\mathrm{mR}$ NAS, can function as substrates for the CAL reaction.

Allelic discrimination in probe ligation-based assays rests on the ability of ligase to distinguish single-base mismatches. The ligation reaction requires only that the terminal and penultimate nucleotides on both sides of the junction of the two probes be base-paired correctly; mismatches located elsewhere in the probe do not prevent ligation. ${ }^{(3,20,35)}$ For this reason, the test will be less affected by DNA sequence polymorphisms than methods relying exclusively on melting temperature. ${ }^{(37)}$ Probes differing in their denaturation temperatures owing to variations in their length and relative GC content can be readily multiplexed in one reaction because specificity is determined primarily by probe ligation. In addition, by using different fluorescent dyes to label oligonucleotide probes, the efficiency of the CAL method can be increased even more.

A crucial factor in determining the utility of a clinical assay for distinguishing two alleles differing by a single base pair is the signal-to-noise ratio. Like $\mathrm{CAL}$, the ligase chain reaction (LCR) accomplishes both amplification and singlenucleotide discrimination in one tube. LCR uses four oligonucleotide probes complementary to both target DNA strands and produces exponential increases in ligation products. ${ }^{(2)}$ However, in LCR, signal-to-noise ratios are high because background target-independent ligation produces a product indistinguishable from the target-specific product, a serious obstacle that hinders use of LCR for diagnostic genetics. In OLA and $\mathrm{CAL}$, amplification is linear but there is absolutely no background, target-independent ligation (Fig. 5C).

Genetic diseases frequently result from single-base-pair substitution mutations or small deletion and insertion mutations. ${ }^{(18,19)}$ Strains of bacterial and viral pathogens also can be distinguished often by variations in single-nucleotide sequences. For example, point mutations in HIV reverse transcriptase produce viral strains resistant to antiviral drugs. ${ }^{(38)}$ Single-point mutations resulting in activation of proto-oncogenes or inactivation of tumor suppressor genes have been associated with many human cancers. ${ }^{(39)}$ The CAL method described in this paper provides in one assay the advantages of both a polymerase-based and a ligase-based amplification technique, and, as such, it should find wide application in molecular genetic analyses of point mutations and small deletions or insertion mutations. For example, the sensitivity and accuracy of the CAL procedure make it well-suited for analysis of genetic changes in cancer cells that are often present in low abundance in tissue samples.

\section{ACKNOWLEDGMENTS}

I thank Bill Giusti and Tess Adriano for their expert assistance in preparing oligonucleotides. I especially thank Eric Shulse and the Applied Biosystems Division of Perkin-Elmer Corporation for supporting this work.

\section{REFERENCES}

1. Saiki, R.K., D.H. Gelfand, S. Stoffel, S.S. Scharf, R.T. Higuchi, G.T. Horn, and K.B. Mullis. 1988. Primer-directed enzymatic amplification of DNA with a thermostable DNA polymerase. Science 239: 487491.

2. Barany, F. 1991. The ligase chain reaction in a PCR world. PCR Methods Applic. 1: 516.

3. Landegren, U., R. Kaiser, J. Sanders, and L. Hood. 1988. A ligase-mediated gene detection technique. Science 241: 10771080.

4. Fahy, E., D.Y. Kwoh, and T.R. Gingeras. 1992. Self-sustained sequence replication (3SR): An isothermal transcription-based amplification system alternative to PCR. PCR Methods Applic. 1: 25-33.

5. Guatelli, J.C., K.M. Whitfield, D.Y. Kwoh, K.J. Barringer, D., D. Richman, and T.R. Gingeras. 1990. Isothermal, in vitro amplification of nucleic acids by a multienzyme reaction modeled after retroviral replication. Proc. Natl. Acad. Sci. 87: 1874-1878.

6. Kalin, I., S. Shephard, and U. Candrian. 1992. Evaluation of the ligase chain reaction (LCR) for the detection of point mutations. Mutat. Res. 283: 119-123.

7. Lagerstrom, M., J. Parik, H. Malmgren, J. Stewart, U. Pettersson, and U. Landegren. 1991. Capture PCR: Efficient amplification of DNA fragments adjacent to a known sequence in human and YAC DNA. PCR Methods Applic. 1: 111-119. 
8. Cha, R.S. and W.G. Thilly. 1993. Specificity, efficiency, and fidelity of PCR. PCR Methods Applic. 3: S18-S29.

9. Edwards, M.C. and R.A. Gibbs. 1994. Multiplex PCR: Advantages, development, and applications. PCR Methods Applic. 3: S65-S75.

10. Ferrie, R.M., M. Schwarz, N.H. Robertson, S. Vaudin, M. Super, G. Malone, and S. Little. 1992. Development, multiplexing, and application of ARMS tests for common mutations in the CFTR gene. Am. J. Hum. Genet. 51: 251-262.

11. Fregeau, C.J. and R.M. Fourney. 1993. DNA typing with fluorescently tagged short tandem repeats: A sensitive and accurate approach to human identification. BioTechniques 15: 100-119.

12. Gilbert, J., M.D. Norris, M. Haber, M. Kavallaris, G.M. Marshall, and B.W. Stewart. 1993. Determination of $\mathrm{N}$-myc gene amplification in neuroblastoma by differential polymerase chain reaction. Mol. Cell. Probes 7: 227-234.

13. Mansfield, E.S. 1993. Diagnosis of Down syndrome and other aneuploidies using quantitative polymerase chain reaction and small tandem repeat polymorphisms. Hum. Mol. Genet. 2: 43-50.

14. Skolnick, M.H. and R.B. Wallace. 1988. Simultaneous analysis of multiple polymorphic loci using amplified sequence polymorphisms (ASPs). Genomics 2: 273279.

15. Miyada, C.G. and R.B. Wallace. 1987. Oligonucleotide hybridization techniques. In Methods in enzymology, vol. 154: Recombinant DNA part E (ed. R. Wu and L. Grossman), pp. 94-107. Academic Press, New York.

16. Chehab, F. and J. Wall. 1992. Detection of multiple cystic fibrosis mutations by reverse dot blot hybridization: A technology for carrier screening. Hum. Genet. 89: 163-168.

17. Barany, F. 1991. Genetic disease detection and DNA amplification using cloned thermostable ligase. Proc. Natl. Acad. Sci. 88: 189-193.

18. Eggerding, F.A., D. Iovannisci, E. Brinson, P. Grossman, and E. Winn-Deen. 1995. A fluorescent-based oligonucleotide ligation assay for analysis of cystic fibrosis transmembrane conductance regulator gene mutations. Hum. Mut. 5: 153-165.

19. Nickerson, D.A., R. Kaiser, S. Lappin, J. Stewart, L. Hood, and U. Landegren. 1990. Automated DNA diagnostics using an ELISA-based oligonucleotide ligation assay. Proc. Natl. Acad. Sci. 87: 8923-8927.

20. Whiteley, N.M., M.W. Hunkapiller, and A. Glazer. 1989. Detection of specific sequences in nucleic acids. U.S. patent no. $4,883,750$.

21. Chirgwin, J.M., A.E. Przybyla, R.J. MacDonald, and W.J. Rutter. 1979. Isolation of biologically active ribonucleic acid from source enriched in ribonuclease. Biochemistry 18: 5294-5296.

22. Giusti, W.G. and T. Adriano. 1993. Synthesis and characterization of $5^{\prime}$-fluorescent-dye-labeled oligonucleotides. $P C R$ Methods Applic. 2: 223-227.

23. Barany, F. and D.H. Gelfand. 1991. Cloning, overexpression and nucleotide sequence of a thermostable DNA ligase-encoding gene. Gene 109: 1-11.

24. Grossman, P., W. Bloch, E. Brinson, C. Chang, F. Eggerding, S. Fung, D. Iovannisci, S. Woo, and E. Winn-Deen. 1994. High-density multiplex detection of nucleic acid sequences: Oligonucleotide ligation assay and sequence-coded separation. Nucleic Acids Res. 22: 4527-4534.

25. Tsui, L.-C. 1992 . The spectrum of cystic fibrosis mutations. Trends Genet. 8: 392398.

26. Zielenski, J., R. Rozmahel, D. Bozon, B-S. Kerem, Z. Grzelczak, J.R. Riordan, J. Rommens, and L.-C. Tsui. 1991. Genomic DNA sequence of the cystic fibrosis transmembrane conductance regulator (CFTR) gene. Genomics 10: 214-228.

27. Breslauer, K.J., R. Frank, H. Blocher, and L.A. Marky. 1986. Predicting DNA duplex stability from the base sequence. Proc. Natl. Acad. Sci. 83: 3746-3750.

28. Chou, Q., M. Russell, D.E. Birch, J. Raymond, and W. Bloch. 1992. Prevention of pre-PCR mis-priming and primer dimerization improves low-copy-number amplifications. Nucleic Acids Res. 20: 17171723.

29. Seyama, T., T. Ito, T. Hayashi, T.Mizuno, N. Nakamura, and M. Akiyama. 1992. A novel blocker-PCR method for detection of rare mutant alleles in the presence of an excess amount of normal DNA. Nucleic Acids Res. 20: 2493-2496.

30. Holland, P.M., R.D. Abramson, R. Watson, and D.H. Gelfand. 1991. Detection of specific polymerase chain reaction product by utilizing the $5^{\prime} \rightarrow 3^{\prime}$ exonuclease activity of Thermus aquaticus DNA polymerase. Proc. Natl. Acad. Sci. 88: 72767280.

31. Wu, D.Y., L. Ugozzoli, B.K. Pal, J. Qian, and R.B. Wallace. 1991. The effect of temperature and oligonucleotide primer length on the specificity and efficiency of amplification by the polymerase chain reaction. DNA Cell Biol. 10: 233-238.

32. Kwok, S., D.E. Kellogg, N. McKinney, D. Spasic, L. Goda, C. Levenson, and J.J. Sninsky. 1990. Effects of primer-template mismatches on the polymerase chain reaction: Human immunodeficiency virus type 1 model studies. Nucleic Acids Res. 18: 999-1005.

33. Schuchard, M., G. Sarkar, T. Ruesink, and T.C. Spelsberg. 1993. Two-step "hot" PCR amplification of GC-rich avian c-myc sequences. BioTechniques 14: 390-394.

34. Kuppuswamy, M.N., J.W. Hoffmann, C.K.
Kasper, S.G. Spitzer, S.L. Groce, and S.P. Bajaj. 1991. Single nucleotide primer extension to detect genetic diseases: Experimental application to hemophilia B (factor IX) and cystic fibrosis genes. Proc. Natl. Acad. Sci. 88: 1143-1147.

35. Wu, D.Y. and R.B. Wallace. 1989. The ligation amplification reaction (LAR) - Amplification of specific DNA sequences using sequential rounds of templatedependent ligation. Genomics 4: 560-569.

36. Wetmur, J.G. 1991. DNA probes: Applications of the principles of nucleic acid hybridization. In Critical reviews in biochemistry and molecular biology 26: 227-259. CRC Press, Boca Raton, FL.

37. Kobayashi, K., M.R. Knowles, R.C. Boucher, W.E. O'Brien, and A.L. Beaudet. 1990. Benign missense variations in the cystic fibrosis gene. Am. J. Hum. Genet. 47: 611-615.

38. Saint Clair, M.H., J.L. Martin, G. TudorWilliams, M. Bach, C. Vavro, D. King, P. Kellam, S. Kemp, and B. Larder. 1991. Resistance to ddI and sensitivity to AZT induced by a mutation in HIV-1 reverse transcriptase. Science 253: 1557-1559.

39. Bos, J.L. 1989. Ras oncogenes in human cancer: A review. Cancer Res. 49: 46824689.

Received December 27, 1994; accepted in revised form April 18, 1995. 


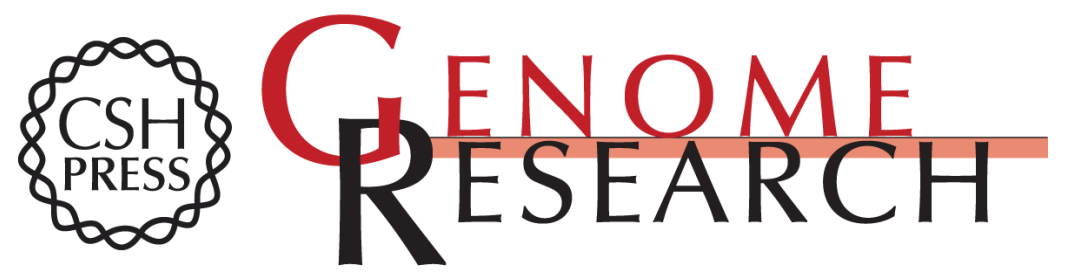

\section{A one-step coupled amplification and oligonucleotide ligation procedure for multiplex genetic typing.}

F A Eggerding

Genome Res. 1995 4: 337-345

References This article cites 36 articles, 10 of which can be accessed free at: http://genome.cshlp.org/content/4/6/337.full.html\#ref-list-1

License

Email Alerting

Receive free email alerts when new articles cite this article - sign up in the box at the Service top right corner of the article or click here.

\section{Affordable, Accurate Sequencing.}

To subscribe to Genome Research go to: https://genome.cshlp.org/subscriptions 